\title{
Perceptions of Marketing Journals by Senior Academics in Australia and New Zealand
}

\author{
Gillian Sullivan Mort, Janet R. McColl-Kennedy, Geoffrey Kiel \& Geoffrey N. Soutar
}

\begin{abstract}
Increasingly, business schools are under pressure to produce quality outputs, including high quality international refereed journal publications. Understanding senior Australian and New Zealand marketing academics' views of journal quality is valuable to individual scholars and to the marketing discipline. This paper presents the findings of a study of such perceptions provided by senior academics in Australia and New Zealand. A survey containing a comprehensive list of 73 journals was sent to all professorial members of ANZMAC and Heads of Marketing Schools in Australia and New Zealand, with an overall response rate of $45 \%$. Respondents rated the journals on a 5-point quality scale and means of ratings were used to establish overall rank. The results suggested that, while senior faculty in Australia and New Zealand have their own distinct perceptions of journal quality, these views are not inconsistent with international views. The implications of the results and directions for future research are discussed.
\end{abstract}

Keywords: Journal rankings, Journal perceptions, Australian and New Zealand Marketing

\section{Introduction}

Refereed journal publications are a standard way through which academics disseminate knowledge and considerable emphasis is placed on publication in international peer reviewed journals. As marketing has developed the number of such journals has increased dramatically (Baumgartner and Pieters, 2003) and over 550 such journals are listed in Cabell's Directory (Cabell, 1997-98) providing guidance on publishing outlets appropriate for research in marketing. Increasingly, specialised outlets have emerged for specific interest areas, following the lead of the Journal of Retailing established in 1925. In addition, the perceived quality of existing journals has changed and the academic environment has become increasingly competitive, with business schools coming under increased pressure to produce high quality outputs. Consequently, marketing academics in Australia and New Zealand are required to make judgements about the quality of a growing number of journals.

Despite a number of attempts to evaluate journals most, until very recently, have been undertaken in the United
States (cf. Fry, Walters and Scheuermann, 1985; Luke and Doke, 1987; Hult, Neese and Bashaw, 1997) and reflect the views of American academics during the 1980s and 1990s. Notable exceptions have been work by Polonsky and others in the Asia Pacific region (Polonsky, Jones and Kearsley, 1999; Polonsky and Waller, 1993), a specific British study by Easton and Easton (2003) and a worldwide survey conducted by Theoharakis and Hirst (2002). The marketing discipline in Australia and New Zealand has continued to develop and mature, reflecting a dynamic fusion of the discipline's American, European and Asia Pacific characteristics. Given the scarcity of Australian and New Zealand rankings, however, marketing academics in Australia and New Zealand have relied largely on American based rankings and/or personal evaluations and word of mouth.

This paper attempts to address this deficit and move such evaluations from tacit to formal knowledge by reporting the findings of a survey of the perceptions of senior marketing academics in Australia and New Zealand. Respondents evaluated a comprehensive list of 73 journals on a 5-point scale ranging from "excellent" (publishes the highest quality research) to "poor" 
(publishes research of marginal quality). The paper reports a simple, perceived quality ranking, compares our study with the rankings of other similar studies and identifies senior faculty's perceptions of the top journals in key research specialisations.

\section{Publication Imperative}

The need to publish is widely known and understood (Moxley, 1992). As early as 1988, department chairs indicated that research was the major factor in evaluating faculty performance (D'Onofrio, Slama and Tashchian, 1988). Publication in refereed journals is a standard strategy for disseminating research knowledge and fulfilling the criteria for research productivity (Hult, Neese and Bashaw, 1997). While the publication of scholarly books is a continuing tradition in European marketing schools, European marketing academics also publish in refereed journals in order to reach a wider audience in a more timely manner, with the added testament to quality afforded by an authoritative editorial board and a double blind peer review process. Informed by European and North American research traditions, and latterly developing a distinct voice, Australian and New Zealand marketing academics have generally published in refereed journals. It could be argued that they are, however, disadvantaged by having relatively few local or regional journals, but advantaged by writing in English and, thus, are able to readily access North American, European and other English language journals. Moreover, marketing has continued to develop, with significant specialisation and an increasing number of journals that reflect these specialist fields (Baumgartner and Pieters, 2003; Malhotra, 1999).

Research funding and faculty appointment and promotion has become increasingly competitive and the perceived quality of publications is increasingly important. For the individual, publication quality is used as evidence of scholarship, while, at a university or school level, quality is used for accreditation, funding and prestige purposes (Bakir, Vitell and Rose, 2000). One proxy for a publication's quality is the journal itself. Consequently, marketing academics are increasingly faced with a need to assess the quality of a large number of journals to find the best outlet for their work, to provide a measure of the performance of fellow academics and to ensure that the wider academic community understands marketing academics' scholarship.

\subsection{Assessments of Contribution to Knowledge}

It may be argued that a peer-reviewed journal, by its nature, only publishes material that contributes to knowledge and that all publications are equal. This may be the position taken by Australia's Department of Education, Science and Training (DEST) in its tradition of awarding equal value to publications in all peerreviewed journals. It can be argued that such an approach measures productivity, but not scholarship (Kirkpatrick and Locke, 1992). It is more generally argued (borrowing from Orwell, 1951) that, while all publications are equal, some are more equal than others. That is, some publications make a stronger contribution to knowledge and measures of scholarship need to be broader than all-inclusive counts (Kirkpatrick and Locke, 1992). The necessity to evaluate publications arises from a need to identify stronger contributions to knowledge for a variety of purposes, such as evaluating individual academic or departmental performance, informing research students and mentoring junior faculty.

An article's contribution to knowledge can be evaluated in a number of ways (Hult, Neese and Bashaw, 1997; Kirkpatrick and Locke, 1992; Van Fleet, McWilliams and Siegel, 2000). First, scholars individually evaluate a paper as contributing or not contributing to the discipline and second as contributing or not contributing to their own work. Second, peers or senior scholars, at the request of review panels, carry out evaluations in their role as respected scholars. Many are reported as considering that their own personal evaluation of a paper's contribution to the discipline is fairer and more accurate in the context of reviews for tenure, promotion and other similar purposes than other alternatives (Van Fleet, McWilliams and Siegel, 2000). When a personal evaluation is made, judgement plays a significant part and the expertise and skill of the judge is crucial.

A paper's contribution to knowledge may also be assessed by its citation rate (Kirkpatrick and Locke, 1992). However, not all journals appear in citation indexes, with newness or specialisation being common reasons for exclusion. There is also some discussion about whether early or late citation makes a difference (Garfield, 1998), being cited soon after publication indicating an initial impact, while later citation may mean a more lasting contribution. Citation rates are also noted as helpful in assessing an individual article's contribution but are not as helpful in developing target 
journals as part of a publication strategy, as citation rates apply to individual articles not the publication outlet itself.

\subsection{Perceived Quality of the Journal}

Yet another measure of a paper's contribution to knowledge is the (perceived) quality of the journal in which it appears, where the overall quality of the journal acts as a proxy for the quality of individual papers within that journal. Journal quality may be inferred by the acceptance rate of papers submitted to the journal. However, reliance on acceptance rates is problematic as there is no generally accepted measure for arriving at acceptance rates and, thus, their meaning is unclear. Further, reported acceptance rates may not be accurate, acceptance rates vary across fields and across time and acceptance rates do not necessarily correlate with other measures of journal ranking (Van Fleet, McWilliams and Siegel, 2000).

The quality of a journal can also be assessed subjectively. Such assessments may develop after years of experience, by reading and evaluating work and acting as a reviewer or editor. Such knowledge is part of a scholar's tacit knowledge (Armbrecht et al., 2001). Such assessments of journal quality by senior academics may be conveyed during the doctoral training process, the induction and mentoring of faculty or among research collaborators seeking publication outlets. Theoharakis and Hirst (2002) found that familiarity with a journal as a member of the editorial board or author leads to a more favourable evaluation of a journal and, thus, quality perceptions may depend significantly on a researcher's interests. They also found that there were significant differences in perceptions between North American, European, Asia and Australian and New Zealand segments.

\section{Moving from Tacit to Codified Knowledge}

Senior faculty in the process of faculty appointment, confirmation, promotion and awarding of research grants are often required to make assessments of journal quality. While this knowledge remains tacit it is generally not amenable to discussion, examination or indeed development and change. Such tacit knowledge can form part of what is termed "stickiness" (von Hippel, 1998) and may well prevent knowledge flows resulting in competitive advantage for those "in the know" and as a barrier to those without this knowledge. Moving from tacit to codified knowledge makes knowledge more widely available and more amenable to knowledge management strategies and thus more imitable. Codifying senior faculty perceptions of journal quality is likely to make explicit the judgement criteria that are, at present, implicit or tacit.

As one strategy in moving from tacit to codified knowledge, perceptions of journal quality can be formed through internally or externally developed lists (e.g. DuBois, 2000; Enomoto, 1993; Hult, Neese and Bashaw, 1997; Mylonopoulos and Theoharakis, 2001; Nisonger, 1999; Trieschmann et al., 2000; Van Fleet, McWilliams and Siegel, 2000). Internal lists, like those that are restricted to one department or school, can suffer from political bias and create a "ghetto" mentality if they vary widely from scholarly norms (Van Fleet, et al., 2000).

A number of benefits of "external" lists have been noted (Van Fleet, et al., 2000). They can provide an explicit measure of the value of research output, establish publication targets, reduce uncertainty in planning and evaluation, guide publication strategies, provide information on journal quality, reduce time and effort in evaluations, provide defensible information in grievance situations and are useful in benchmarking and baselining. It has also been noted that many faculty prefer to have access to a perceived ranking of journals as a guide to decision making when asked to evaluate the quality of others' work (Hult, et al., 1997).

Recent discussion on the ELMAR email list (for example by Armstrong, Dann, Kohli and others during June to November 2002) focused on the disadvantages of "external" lists as being, among other things, detrimental to the reporting of useful research findings and detrimental to innovation in the discipline and ranking the unrankable. It is widely accepted that highly innovative methods, approaches and topics are typically regarded as too new or too risky for publication in top journals. However, as part of the ELMAR discussion, Brumbaugh (2002) cogently argued that "informal" or tacit lists are in frequent use by all business schools. Brumbaugh also noted that, while newer business schools may formalise their lists, they often have longer lists of well-regarded journals. Theoharakis and Hirst (2002) in their recent research on lists noted that they targeted faculty from leading business schools in their survey, as they tend to place importance on high quality research and have often developed formal criteria, such as lists, for evaluating research output.

Lists may operationalise quality in a number of ways, including popularity, impact, overall rank, being placed 
in the top 10 per cent of journals, ability to disseminate scholarly knowledge or the perceived quality of published material. Implying quality based largely on frequency of submission to a government agency and the institution's rating (such as in Easton and Easton's 2003 study) is problematic. Indeed, the Easton and Easton study reported the top "implied quality" entry as Advances in Consumer Research, which is not a journal but, rather, the published proceedings of the Association for Consumer Research conference. Further, the Easton and Easton (2003) RAE "implied journal quality" (RIJQ index) was based solely on British data and uses the RAE assessments that apply only to British higher education institutions. Easton and Easton (2003, p. 19) acknowledged serious flaws in the listing as "there are a number of very serious caveats to be entered before accepting RIJQ as a valid indicator of journal quality." Although, they saw the one advantage of the RIJQ listing as being that "it is useful in terms of middle to low quality journals" (Easton and Easton 2003, p. 20).

While there is no agreed theory underlying the development of such lists (Van Fleet, et al., 2000), the present research used a knowledge management framework (Armbrecht et al., 2001; Schulz and Jobe, 2001) and reports a list of marketing journals based on the perceptions of heads of school and professors of marketing in Australia and New Zealand in order to codify tacit into explicit knowledge. The purpose of making tacit knowledge explicit is to support an open, productive and effective culture, as well as helping academics to find appropriate outlets for their work, assess the performance of fellow academics and communicate marketing academics' scholarship to the wider regional academic community.

\section{Methodology}

The present study's objective was to rank marketing journals according to the perceptions of quality of senior marketing academics in Australia and New Zealand. The operational definition of the sample frame was academics at professorial level in marketing or holding a head of marketing school position (or equivalent) in Australia and New Zealand. While other operationalisations could have been adopted, such as all "productive researchers using DEST data", professors and heads of department were targeted because of their leadership role in the discipline. The leadership provided as supervisors and examiners of research higher degree theses, in grant evaluation and in employment and promotion decisions, as well as their function as opinion leaders and knowledge managers, provides a distinct perspective not usually available to academics. While it is acknowledged that some head of department roles may be administrators, such people are also generally active researchers and are academics with extensive experience. For similar reasons, Theoharakis and Hirst (2002) targeted faculty from leading business schools.

In the current study respondents were asked to rate 73 journals identified by title and publisher. Although the inclusion of publisher details may have biased the sample by framing respondents' perceptions of the journals, it was considered important as a means of aiding participants' recall, given the similarity of many journal names and the extensive list they were being asked to assess.

The survey instrument, including a cover letter explaining the purpose of the research and instructions for respondents, was first tested in a pilot study. The final survey was emailed to 73 senior marketing academics (professorial members of the Australian and New Zealand Marketing Academy (ANZMAC) and the heads of school of all marketing schools in Australia and New Zealand). Details of professorial members were obtained from the ANZMAC membership database. The heads of school database was created by searching all Australian and New Zealand university websites, using a master list of AVCC member universities for Australia as the basis for the list. A follow up survey was administered 10 days after the initial mail out and a third reminder was sent another week later. Thirty-three faculty members responded, providing a $45 \%$ response rate.

Following Luke and Doke (1987), the journals were selected because they were frequently cited, had appeared in previous rankings and/or were nominated by members of the research team. A relatively large number of journals was included in an attempt to adequately represent the breadth of research interests and scholarship in the marketing discipline in Australia and New Zealand. General management journals with a strong practitioner orientation, such as the Harvard Business Review, were omitted. Also omitted were publications in any conference proceedings, including the ANZMAC conference and other well-known international conferences, such as the proceedings of the American Marketing Association's Summer and Winter Educators' Conferences, the proceedings of the Academy of Marketing Science and Advances in Consumer Research. However, it is interesting to note that Advances in Consumer Research is sometimes viewed as 
a journal, with Hult et al. (1997) ranking Advances in Consumer Research at number 13 out of 40 journals.

Respondents rated each journal's quality on a 5-point scale (ranging from "poor", "fair", "good", "very good" to "excellent"). A "cannot rate" category was used as a measure of journal familiarity (Luke and Doke, 1987). Participants were also asked to add other journals they thought should have been included and were given an opportunity to make comments.

The journals were ranked according to their mean and a Spearman correlation coefficient was computed between the journal rankings and the rankings from the percentages of those who could not rate a journal to see whether there was a relationship between journal rating and familiarity.

\section{Results}

The journal ranking obtained is provided in Table 1 . The means varied from 1.2 to 4.9. The Journal of Consumer Research and Journal of Marketing received near perfect scores (4.9 and 4.8 respectively). Ten journals were rated as "very good" to "excellent", 31 were rated as "good" to "very good", 25 as "fair" to "good", with seven falling into the lowest category, "poor" to "fair". The top $10 \%$ were Journal of Consumer Research; Journal of Marketing; Journal of Marketing Research; Marketing Science; Journal of Retailing; Journal of Academy of Marketing Science; and Journal of International Business Studies.

The study also identified the top journals in a number of research specialisations. The Journal of Consumer Research was identified as the top journal in consumer behaviour; the Journal of Marketing Research, the top journal in marketing research; the Journal of Retailing, the top journal in retailing; the Journal of International Business Studies, the top in international marketing; the Journal of Advertising, the top in advertising; the Journal of Public Policy and Marketing, the top in the field of public policy; the Journal of Service Research, the top journal in services; Industrial Marketing Management, the top in industrial marketing (business to business); and the Journal of Strategic Marketing the top journal in strategy.

Of particular interest, the Australasian Marketing Journal (amj) was viewed as "good" to "very good". It also ranked in the top five for familiarity (knowledge of content of the journal). In contrast, the Australian Journal of Market Research was placed in the "fair" to "good" category, with 39\% unfamiliar with the journal. Other local journals (Marketing Bulletin and Marketing) were similarly ranked, falling just on or below the lowest group cut-off. This suggests amj is considered the most prestigious Australasian marketing journal.

Spearman's correlation (rho) between quality and "cannot rate" was - $0.67(\mathrm{p}=0.00)$, suggesting a strong relationship between perceived quality and familiarity. The seven "bottom" journals surveyed had, for example, between $52 \%$ and $88 \%$ of responses in the "cannot rate" category.

Table 2 provides a comparison between the results of the present study and those of Theoharakis and Hirst (2002), Polonsky et al. (1999) and Hult et al. (1997). The Journal of Consumer Research, the Journal of Marketing, and the Journal of Marketing Research are ranked in the top three in all lists, except in those of Polonsky et al. (1999). It is, however, important to note that the Polonsky et al. (1999) looked at accessibility of journals in Australian university library holdings (either in hard copy or full text electronic format) and not at academics' perceptions of journals. The Journal of Academy of Marketing Science, Marketing Science, the International Journal of Research in Marketing and the Journal of Retailing are also consistently ranked very high.

Table 3 lists the journals that were common to all four studies. A Spearman rank correlation between the studies found high correlations between the various results. The correlation between the present study and Theoharakus and Hirst's (2002) recent international survey among leading business schools was 0.89 and with Hult et al.'s (1997) study was 0.65. A much weaker correlation was found with Polonsky et al.'s (1999) study, which is not surprising given the different focus of their study.

\section{Conclusions}

The present paper is a timely and useful report about the perceptions senior Australian and New Zealand marketing academics have of the quality of a comprehensive list of marketing journals. Mindful of the caveats involved in presenting any such list, discussed further below, the paper presents information Australasian marketing academics need to know. Academics now have a codified, rather than a tacit, knowledge base to inform their decision-making. Active researchers should understand more clearly the basis on which decisions are made for grants, employment and tenure decisions. Novice researchers and students can also gain increased insight into the "collective mind" of 
Table 1: Australian and New Zealand Senior Academics' Rankings of Marketing Journals

\begin{tabular}{|c|c|c|c|c|}
\hline Rank & Journal & Mean & $\mathrm{N}$ & $\%$ Can't Rate \\
\hline 1 & Journal of Consumer Research & 4.9 & 27 & $18 \%$ \\
\hline 2 & Journal of Marketing & 4.8 & 33 & $0 \%$ \\
\hline 3 & Journal of Marketing Research & 4.6 & 33 & $0 \%$ \\
\hline 4 & Marketing Science & 4.5 & 23 & $30 \%$ \\
\hline 4 & Journal of Retailing & 4.5 & 24 & $27 \%$ \\
\hline 4 & Journal of the Academy of Marketing Science & 4.5 & 32 & $3 \%$ \\
\hline 7 & Journal of International Business Studies & 4.4 & 23 & $30 \%$ \\
\hline 8 & International Journal of Research in Marketing & 4.3 & 31 & $6 \%$ \\
\hline 9 & Journal of Advertising & 4.1 & 24 & $27 \%$ \\
\hline 10 & Marketing Letters & 4.0 & 24 & $27 \%$ \\
\hline 11 & European Journal of Marketing & 3.9 & 32 & $3 \%$ \\
\hline 11 & Journal of Business Research & 3.9 & 31 & $6 \%$ \\
\hline 13 & Journal of Public Policy \& Marketing & 3.8 & 18 & $46 \%$ \\
\hline 13 & Journal of Service Research & 3.8 & 19 & $42 \%$ \\
\hline 13 & Journal of Advertising Research & 3.8 & 25 & $24 \%$ \\
\hline 16 & Journal of Marketing Management & 3.7 & 29 & $12 \%$ \\
\hline 16 & Industrial Marketing Management & 3.7 & 24 & $27 \%$ \\
\hline 16 & Psychology \& Marketing & 3.7 & 21 & $36 \%$ \\
\hline 19 & Journal of Macromarketing & 3.6 & 21 & $36 \%$ \\
\hline 19 & Journal of Strategic Marketing & 3.6 & 25 & $24 \%$ \\
\hline 21 & Advances in International Marketing & 3.5 & 14 & $58 \%$ \\
\hline 21 & Journal of Consumer Psychology & 3.5 & 18 & $46 \%$ \\
\hline 23 & International Marketing Review & 3.4 & 24 & $27 \%$ \\
\hline 23 & Journal of Market Research & 3.4 & 24 & $27 \%$ \\
\hline 23 & Journal of International Marketing & 3.4 & 22 & $33 \%$ \\
\hline 23 & Journal of Consumer Behaviour & 3.4 & 20 & $39 \%$ \\
\hline 27 & Marketing Theory & 3.3 & 17 & $49 \%$ \\
\hline 28 & Journal of Personal Selling \& Sales Management & 3.2 & 10 & $70 \%$ \\
\hline 28 & Journal of Market-Focused Management & 3.2 & 11 & $67 \%$ \\
\hline 28 & International Journal of Market Research & 3.2 & 23 & $30 \%$ \\
\hline 28 & Journal of Retailing \& Consumer Services & 3.2 & 12 & $64 \%$ \\
\hline 28 & Journal of Marketing Education & 3.2 & 26 & $21 \%$ \\
\hline 28 & International Journal of Advertising & 3.2 & 20 & $39 \%$ \\
\hline 34 & Journal of Product \& Brand Management & 3.1 & 28 & $15 \%$ \\
\hline 34 & Journal of Services Marketing & 3.1 & 27 & $18 \%$ \\
\hline 34 & Journal of Brand Management & 3.1 & 23 & $30 \%$ \\
\hline 34 & Australasian Marketing Journal & 3.1 & 32 & $3 \%$ \\
\hline 38 & Journal of Consumer Marketing & 3.0 & 23 & $30 \%$ \\
\hline 38 & International Journal of Retail \& Distribution Management & 3.0 & 18 & $46 \%$ \\
\hline 38 & Journal of Hospitality \& Tourism Research & 3.0 & 12 & $64 \%$ \\
\hline 38 & Journal of Marketing Channels & 3.0 & 8 & $76 \%$ \\
\hline 42 & Journal of Marketing Communications & 2.9 & 19 & $42 \%$ \\
\hline 42 & Journal of Marketing Theory \& Practice & 2.9 & 17 & $49 \%$ \\
\hline 42 & Marketing Intelligence \& Planning & 2.9 & 27 & $18 \%$ \\
\hline 45 & Marketing Management & 2.8 & 19 & $42 \%$ \\
\hline 45 & Journal of Interactive Marketing & 2.8 & 14 & $58 \%$ \\
\hline 45 & Journal of Business \& Industrial Marketing & 2.8 & 18 & $46 \%$ \\
\hline 45 & Journal of Health Care Marketing & 2.8 & 16 & $52 \%$ \\
\hline 45 & Journal of Professional Services Marketing & 2.8 & 16 & $52 \%$ \\
\hline 50 & Journal of Euromarketing & 2.7 & 13 & $61 \%$ \\
\hline 50 & Journal of Business to Business Marketing & 2.7 & 21 & $36 \%$ \\
\hline 50 & Vacation Marketing & 2.7 & 6 & $82 \%$ \\
\hline 50 & Journal of Targeting, Measurement \& Analysis for Marketing & 2.7 & 12 & $64 \%$ \\
\hline 54 & Journal of International Marketing \& Marketing Research & 2.6 & 13 & $61 \%$ \\
\hline 54 & Journal of Global Marketing & 2.6 & 15 & $55 \%$ \\
\hline 54 & International Journal of Bank Marketing & 2.6 & 16 & $52 \%$ \\
\hline 54 & Journal of Current Issues \& Research in Advertising & 2.6 & 9 & $73 \%$ \\
\hline 58 & Marketing Research & 2.5 & 19 & $42 \%$ \\
\hline 58 & Journal of Travel Research & 2.5 & 8 & $76 \%$ \\
\hline 58 & Journal of International Consumer Marketing & 2.5 & 11 & $67 \%$ \\
\hline 58 & Journal of Non Profit \& Public Sector Marketing & 2.5 & 11 & $67 \%$ \\
\hline 58 & Journal of Travel and Tourism Marketing & 2.5 & 11 & $67 \%$ \\
\hline 58 & Australian Journal of Market Research & 2.5 & 20 & $39 \%$ \\
\hline 64 & Marketing Education Review & 2.2 & 13 & $61 \%$ \\
\hline 65 & Marketing News & 2.1 & 21 & $36 \%$ \\
\hline 65 & Marketing Bulletin & 2.1 & 22 & $33 \%$ \\
\hline 67 & Marketing & 1.8 & 16 & $52 \%$ \\
\hline 67 & Journal of Database Marketing & 1.8 & 10 & $70 \%$ \\
\hline 69 & Marketing Business & 1.5 & 11 & $67 \%$ \\
\hline 69 & Marketing Week & 1.5 & 13 & $61 \%$ \\
\hline 71 & Sales \& Marketing Professional & 1.3 & 4 & $88 \%$ \\
\hline 72 & Precision Marketing & 1.2 & 5 & $85 \%$ \\
\hline 72 & Direct Marketing & 1.2 & 6 & $82 \%$ \\
\hline
\end{tabular}




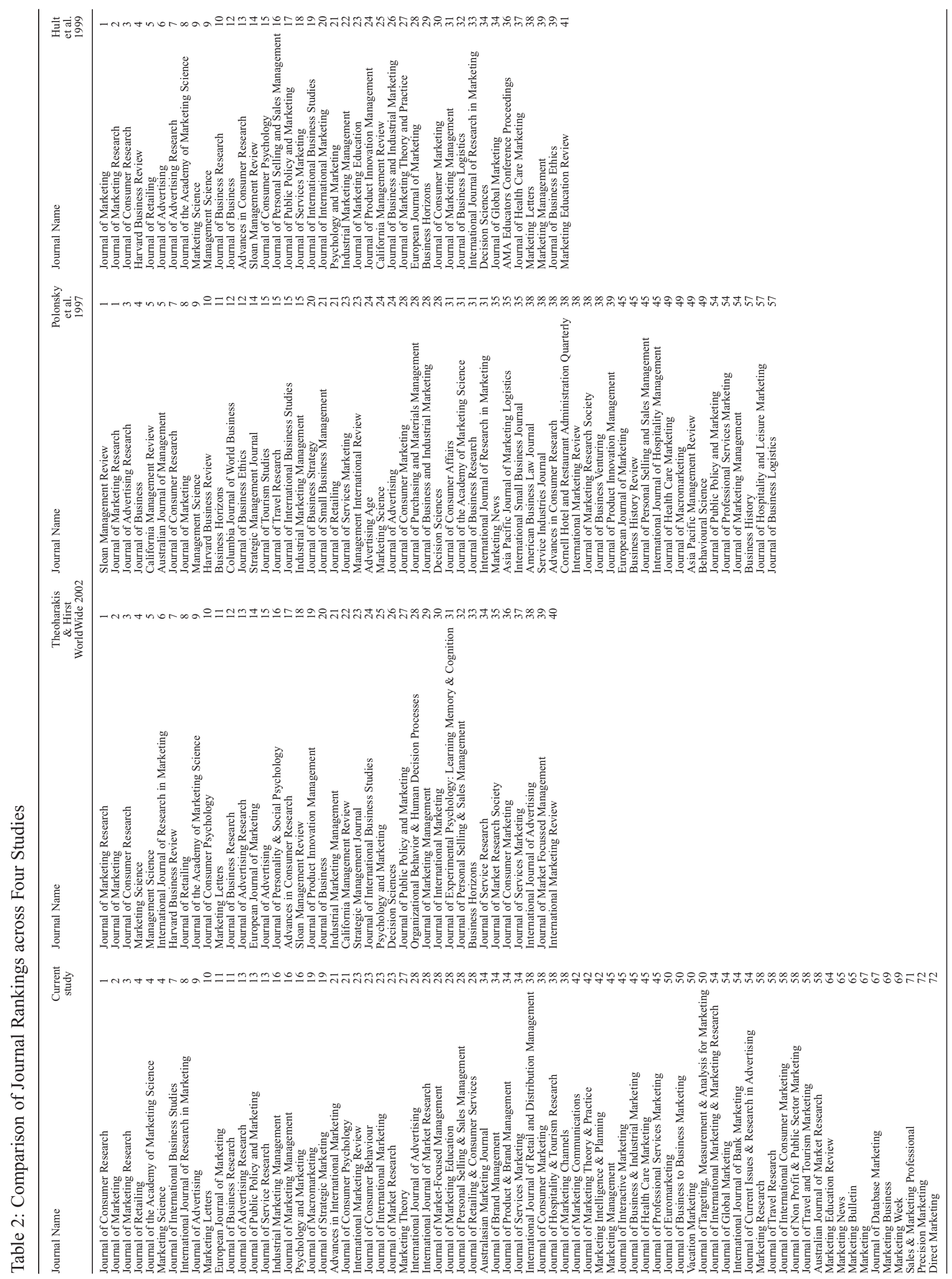


Table 3: Comparison of Journal Rankings across Four Studies*

\begin{tabular}{|c|c|c|c|c|}
\hline Journal Name & $\begin{array}{c}\text { Current } \\
\text { study }\end{array}$ & $\begin{array}{l}\text { Theoharakis } \\
\& \text { Hirst** }\end{array}$ & $\begin{array}{c}\text { Polonsky } \\
\text { et al. }\end{array}$ & $\begin{array}{l}\text { Hult } \\
\text { et al. }\end{array}$ \\
\hline Year study was published & 2004 & 2002 & 1999 & 1997 \\
\hline Journal of Consumer Research & 1 & 3 & 7 & 3 \\
\hline Journal of Marketing & 2 & 2 & 8 & 1 \\
\hline Journal of Marketing Research & 3 & 1 & 1 & 2 \\
\hline Journal of Retailing & 4 & 8 & 21 & 5 \\
\hline Journal of the Academy of Marketing Science & 4 & 9 & 31 & 8 \\
\hline Journal of International Business Studies & 7 & 24 & 15 & 19 \\
\hline International Journal of Research in Marketing & 8 & 6 & 31 & 33 \\
\hline Journal of Advertising & 9 & 15 & 24 & 6 \\
\hline European Journal of Marketing & 11 & 14 & 45 & 28 \\
\hline Journal of Business Research & 11 & 12 & 31 & 10 \\
\hline Journal of Advertising Research & 13 & 13 & 3 & 7 \\
\hline Journal of Public Policy and Marketing & 13 & 27 & 54 & 17 \\
\hline Industrial Marketing Management & 16 & 21 & 15 & 22 \\
\hline Journal of Marketing Management & 16 & 29 & 54 & 31 \\
\hline Journal of Personal Selling \& Sales Management & 28 & 32 & 45 & 16 \\
\hline Journal of Services Marketing & 34 & 37 & 23 & 18 \\
\hline Journal of Consumer Marketing & 38 & 36 & 28 & 30 \\
\hline
\end{tabular}

* This table compares only those journals that were common in all four studies.

** Rankings based on a world-wide sample of respondents.

Table 4: Spearman Rank Correlations Among the Four Studies

\begin{tabular}{ccccc}
\hline & Current study & $\begin{array}{c}\text { Theoharakis } \\
\text { \& Hirst } 2002\end{array}$ & $\begin{array}{c}\text { Polonsky } \\
\text { et al. } 1999\end{array}$ & $\begin{array}{c}\text { Hult } \\
\text { et al. } 1997\end{array}$ \\
\hline Current study & 1.000 & $.891^{* *}$ & $.465^{*}$ & $.651^{* *}$ \\
Theoharakis \& Hirst 2002 & $.891^{* *}$ & 1.000 & $.497^{*}$ & $.610^{* *}$ \\
Polonsky et al. 1999 & $.465^{*}$ & $.497^{*}$ & .600 & $.603 *$ \\
Hult et al. 1997 & $.651^{* *}$ & $.610^{* *}$ & $.603 * *$ & 1.000 \\
\hline
\end{tabular}

** Correlation is significant at the .01 level (1-tailed).

* Correlation is significant at the .05 level (1-tailed). 
the senior members of the Australasian marketing academy and may be helped to position their research output more judiciously.

The formalisation of such knowledge, through the formal presentation of such a list, should not only facilitate the dissemination of knowledge but also provide those who disagree with the "list" with the ability to more easily challenge orthodoxy and further promote academic discourse. In developing this survey care was taken to present respondents with a comprehensive list of journals within the limits imposed by the survey method. As a result, an extensive list, more comprehensive than that provided by most previous research, is now available to inform the decisions of academics in the Australian and New Zealand academy when publishing and evaluating marketing scholarship. Moving from tacit to codified knowledge makes knowledge more widely available thus preventing "stickiness" (von Hippel, 1998) and making knowledge and strategies built upon it more imitable. It thus contributes to a more open and productive academic environment within the Australasian marketing community.

Interestingly, although senior Australian and New Zealand marketing academics have developed their own perceptions of the quality of marketing journals, this view is not widely divergent to those expressed in previously published American-based lists and, indeed, these views are generally consistent with the latest international study by Theoharakis and Hirst (2002) which provides a "world-wide" view of marketing journals. It is sometimes argued that the Australasian academic community presents a fusion of American and European traditions. It is notable that, using this lens, the ranking of journals are consistent with the approach of academics in the other parts of the world. The top journals are global in influence and still principally American based. Indeed, nine of the top ten journals, and seventeen of the top twenty journals, are American based, suggesting the significant impact American academic and professional bodies continue to have on our discipline. It is also clear that the leading regional journal (the Australasian Marketing Journal (amj)) is viewed by senior academics as being of "good" to "very good" quality.

Caution should be exercised when employing any list in decision-making. It is often the case that innovative or contrary research is regarded as too risky for "top" journals, which tend to reflect orthodoxy. In addition, even publication in a highly ranked journal serves only as a proxy and does not say anything directly about the quality of an article. Similarly, caution should be exercised when using lists for promotion or other reward purposes, as some journals are not included in the listings. Newer journals are particularly disadvantaged as they may not be included in the list because they were published after the survey had been undertaken and because it takes considerable time for academic staff to become familiar with these new journals. A good example is the Journal of Service Research, which was not included in the Hult et al.'s (1997) study because it was first published after that time (1998). Further, there is a strong correlation between familiarity and the rank of the journal, indicating the need for caution in evaluating the relative quality of the newer journals as newness is a reason for lack of familiarity and, consequently, possibly perceived lower quality.

It must also be recognised that journals may change ranking positions over time. A good example of this is the International Journal of Research in Marketing that has moved from thirty-third position in Hult et al.'s (1997) list to sixth position in Theoharakis and Hirst's (2002) list, and eighth position in this study. Another good example is the Journal of the Academy of Marketing Science that was in fourth position in this survey, but in eighth position in Hult et al.'s (1997) study and ninth in Theoharakis and Hirst's (2002) study.

Finally, it should also be highlighted that, as has been cogently argued elsewhere, even publication in highly ranked journals should be used with other measures, such as citation and peer evaluation, to assess an individual's scholarship (Kirkpatrick and Locke, 1992).

\subsection{Future Research}

We consciously limited our study to the perceptions of senior marketing academics (defined as professors and heads of marketing departments in Australia and New Zealand) as these people play a significant role in knowledge management in the discipline and have a major input into promotions and whether staff appointments are continued. Knowing what is in the minds of such people when they think of high quality journals is useful to all within the discipline and this study has moved these perceptions from tacit to codified knowledge. However, it would be interesting for future studies to undertake a survey across the whole discipline of marketing in Australia and New Zealand and to investigate if there are any significant differences of 
perceptions based on academic rank or experience. Further, it is important that such surveys be undertaken regularly (say every five years) as perceptions of journals change over time as the discipline itself evolves.

\section{References}

Armbrecht, F.M.R., Jr., Chapas, R.B., Chappelow, C.C., Farris, G.F., Friga, P.N., Hartz, C.A., McIlvaine, M.E., Postle, S.R., and Whitwell, G. E., 2001. Knowledge management in research and development. Research Technology Management 44(4), 28-48.

Bakir, A., Vitell, S.J., and Rose, G.M., 2000. Publications in major marketing journals: An analysis of scholars and marketing departments. Journal of Marketing Education 22 (2), 99-107.

Baumgartner, H., and Pieters, R., 2003. The structural influence of marketing journals: A citation analysis of the discipline and its subareas over time. Journal of Marketing 67 (April), 123-139.

Becker, H., 1986. Writing for the Social Scientist: How to Start and Finish Your Thesis, Book or Article. University of Chicago Press: Chicago.

Brumbaugh, A., 2002. Response: Marketing journal rankings. ELMAR, July (www.elmar-list.org).

Cabell, D.W.E. 1997-98. Cabell's Directory of Publishing Opportunities in Management and Marketing. Cabell Publishing Co.: Beaumont, TX.

D’Onfrio, M.J., Slama, M.E. and Tashchian, A., 1988. Faculty evaluation perspectives in colleges of business: How marketing department heads' evaluations differ from those of department heads in other business disciplines. Journal of Marketing Education 10 (Summer), 21-28.

DuBois, F.L., 2000. Ranking the international business journals. Journal of International Business Studies 31 (4), 689-705.

Easton, G. and Easton, D.M. 2003. Marketing journals and the research assessment exercise. Journal of Marketing Management 19 (1/2), 5-25.

Enomoto, C.E., 1993. A stratified approach to the ranking of economics journals. Studies in Economic Analysis 14 (2), 74-94.

Fry, E. H., Walters, C. G., and Scheuermann, L. E., 1985. Perceived quality of fifty selected journals: Academicians and practitioners. Journal of the Academy of Marketing Science 13 (Spring), 352-61.
Garfield, E., 1998. Long term versus short term journal impact: Does it matter? The Physiologist, 41, 113-115.

Hult, G.T.M, Neese, W.T., and Bashaw, R.E., 1997. Faculty perceptions of marketing journals. Journal of Marketing Education 19 (1), 37-52.

Kirkpatrick, S.A., and Locke, E.A., 1992. The development of measures of faculty scholarship. Group and Organization Management 17 (1), 5-23.

Luke, R.H., and Doke, E.R., 1987. Marketing journal hierarchies: Faculty perceptions, 1986-1987. Journal of the Academy of Marketing Science 15 (1), 74-78.

Malhotra, N.K., 1999. Guest editorial: The past, present and future of the marketing discipline. Journal of the Academy of Marketing Science 27 (2), 116-119.

Moxley, J.M., 1992. Publish, Don't Perish: The Scholar's Guide to Academic Writing and Publishing. Greenwood Press: Westport, CT.

Mylonopoulos, N.A., and Theoharakis, V., 2001. Global perceptions of IS journals. Communications of the ACM 44 (9), 29-37.

Nisonger, T.E., 1999. JASIS and library and information science journal rankings: A review and analysis of the last half century. Journal of the American Society for Information Science 50 (11), 1004-1020.

Orwell, G., 1951. Animal Farm: A Fairy Story. Penguin: Harmondsworth, Middlesex.

Polonsky, M.J., Jones, G., and Kearsley, M.J., 1999. Accessibility: An alternative method of ranking marketing journals? Journal of Marketing Education 21 (3), 181-193.

Polonsky, M.J., and Waller, D.S., 1993. Marketing journals and Asia-Pacific marketing academics. AsiaAustralia Marketing Journal 1 (1), 61-69.

Schulz, M., and Jobe, L.A., 2001. Codification and tacitness as knowledge management strategies: An empirical exploration. Journal of High Technology Management Research 12 (1), 139-165.

Theorharakis, V. and Hirst, V. 2002. Perceptual differences of marketing journals: A worldwide perspective. Marketing Letters 13 (4), 389-402.

Trieschmann, J.S., Dennis, A.R., Northcraft, G.B., and Niemi, A.W., Jr., 2000. Serving multiple constituencies in business schools: M.B.A. program versus research performance. Academy of Management Journal 43 (6), 1130-141. 
Van Fleet, D.D., McWilliams, A., and Siegel, D.S., 2000. A theoretical and empirical analysis of journal rankings: The case of formal lists. Journal of Management 26 (5), 839-861.

von Hippel, E. 1998. Economics of product development by users: The impact of 'sticky' local information. Management Science 44 (5), 629-644.

Wayland, J.P., Urban, D.J. and McDermott, D.R. 1992. The role of proceedings in the evaluation of faculty research standards in AACSB-accredited marketing departments. American Marketing Association Summer Educators Conference, 1992, 313-317.

\section{Acknowledgements}

The authors wish to acknowledge the research assistance work of Mary Anne Barclay in the preparation of this paper and thank the three anonymous reviewers for their helpful comments.

\section{Biographies}

Gillian Sullivan Mort, PhD, MBA, MAPS, is a Senior Lecturer at The Australian National University and convenor of the Master of Marketing Program. She is a professional psychologist, consultant and marketing academic who is currently involved in developing a small team of early career marketing academics and doctoral students. She is Chair of the Inaugural Australasian Nonprofit Marketing Conference.

Janet McColl-Kennedy, PhD, BA (Hons), FAMI, Professor of Marketing and Cluster Leader, Marketing, at UQ Business School, University of Queensland. She has published in the Journal of Service Research, Journal of Business Research, The Leadership Quarterly, Journal of Services Marketing, Marketing Theory, International Journal of Human-Computer Studies, Advances in Consumer Research, Australasian Marketing Journal, Journal of International Consumer Marketing, and Marketing Intelligence and Planning.

Geoffrey Kiel, PhD, Professor of Management at UQ Business School and current President of ANZMAC.

Geoffrey Soutar, PhD, Director of the Graduate School of Management at the University of Western Australia. He has been a marketing academic for many years, during which time he has published papers across many areas of marketing and management in many of the journals included in the present study.

\section{Correspondence Addresses}

Gillian Sullivan Mort, School of Business and Information Management, Faculty of Economics and Commerce, The Australian National University, Canberra ACT 0200. Telephone: +61 (2) 6125 3667. Facsimile: +61 (2) 61255005. Email: gillian.mort@anu.edu.au; Janet R. McColl-Kennedy, UQ Business School, University of Queensland, Brisbane, Queensland 4072. Telephone: +61 (7) 3365 6673. Facsimile: +61 (7) 3365 6988. Email: j.mccollkennedy@business.uq. edu.au Geoffrey Kiel, UQ Business School, University of Queensland, Brisbane, Queensland 4072. Telephone: +61 (7) 3365 6758. Facsimile: +61 (7) 3365 6988. Email: g.kiel@gsm.uq.edu.au Geoffrey N. Soutar, Graduate School of Management, University of Western Australia, Perth, Western Australia. Telephone: +61 (8) 9380 7885. Facsimile: +61 (8) 9380 1072. Email: gsoutar@uwa.edu.au 